\title{
Penguatan Efikasi Diri Pedagang Pasar Tradisional melalui Pelatihan Kewirausahaan yang Berorientasi pada Modal Psikologi Positif
}

\author{
Elpisah Amir ${ }^{1}$, Muhammad Hasan ${ }^{2}$ \\ ${ }^{1}$ Program Studi Pendidikan Ekonomi, STKIP Pembangunan Indonesia \\ ${ }^{2}$ Program Studi Pendidikan Ekonomi, Fakultas Ekonomi, Universitas Negeri Makassar
}

\begin{abstract}
Entrepreneurship development programs must not only be carried out in formal education, such as at the level of primary, secondary and tertiary education, but also must be developed in informal and non-formal education in the community. The entrepreneurship program also has to be applied for traditional market traders. The training activity aims to provide an understanding of the importance of positive psychological capital in the management and sustainability of businesses for the traditional market traders. The training activity was conducted at the Laboratory of Economic Education Study Program, Faculty of Economics, Makassar State University, which was attended by traditional market traders from 3 traditional markets in Makassar City. The implementation of this activity strongly supports the entrepreneurship program in the informal sector. Because by doing this program, it can provide added value for traditional market traders in managing the sustainability of their business. There were changes of knowledge and attitudes of traditional market traders after participating in this activity. It could be seen from the increase of the participants' post-test score compared to the pre-test score.
\end{abstract}

Keywords: self-efficacy, positive psychological capital

\section{PENDAHULUAN}

Sektor informal memiliki peranan yang cukup strategis dalam pembangunan ekonomi, khususnya dalam mengatasi kemiskinan dan pengangguran. Hal ini berkaitan pula dengan peranan pendidikan kewirausahaan di sektor informal melalui transformasi nilai dan karakter kewirausahaan dalam aktifitas bisnis atau usahanya. Sektor informal didominasi oleh usaha mikro, kecil dan menengah. Beberapa hasil penelitian menunjukkan bahwa pelaku usaha pada sektor informal banyak didominasi oleh pelaku pada usaha usaha mikro, kecil dan menengah, baik pada negara sedang berkembang, maupun pada negara maju (Bhatt, 2006; Bhowmik, 2007; Hasan, 2013; Hasan, 2014).

Meskipun sektor informal memiliki peranan yang cukup strategis dalam pembangunan ekonomi, hingga saat ini sektor tersebut masih memiliki berbagai macam masalah, khususnya karena sektor ini masih cenderung bersifat subsisten (Imran, 2018). Salah satu aspek yang layak dikedapankan untuk mengatasi hal tersebut adalah pendidikan kewirausahaan yang diimplementasikan di dalam lingkungan keluarga. Pendidikan kewirausahaan pada sektor informal dalam keluarga adalah satusatunya cara yang paling efektif agar keluarga dan usaha mereka dapat terus bertahan (Hasan, 2016; Hasan, 2017; Hasyim et al, 2017; Hasan, 2018).

Keberlangsungan usaha pedagang pasar tradisional dipengaruhi oleh berbagai faktor yaitu motivasi berprestasi, keberanian menghadapi risiko, dan komitmen berwirausaha. Secara lebih spesifik, masalah yang dihadapi oleh pedagang pasar lokal meliputi masalah manajemen. Dari segi manajemen, kelompok usaha pengrajin kayu di Kecamatan Manggala mengahadapi masalah sebagai berikut:

1. Pemilik sebagai pengelola.

2. Berkembang dari usaha kecil-kecilan, karena itu kepercayaan diri yang berlebihan.

3. Tidak membuat perencanaan tertulis.

4. Kurang membuat catatan/pembukuan tertib.

5. Pendelegasian wewenang secara lisan.

6. Kurang mampu mempertahankan mutu.

7. Sangat tergantung pada pelanggan dan pemasok disekitar usahanya. 
8. Kurang membina saluran informasi.

9. Kurang mampu membina hubungan perbankan.

\section{METODE PELAKSANAAN}

Berdasarkan identifikasi masalah, maka metode yang digunakan adalah pelatihan dengan menggunakan model ABCs. Dalam Model ABCs, "A" adalah adversity yaitu peristiwa-peristiwa yang menimbulkan reaksi (emosi negatif) dari individu seperti misalnya kehilangan pekerjaan, putus cinta, kehilangan orang yang dicintai, kesulitan ekonomi, dan lain sebagainya. Suatu peristiwa akan menimbulkan adversitas yang berbeda untuk orang yang berbeda. Hal ini disebabkan oleh pemaknaan yang berbeda- beda terhadap suatu peristiwa yang sama. Adversitas akan mengarahkan pada munculnya perasaan dan tindakan-tindakan tertentu sebagai respon terhadap peristiwa tersebut (konsekuensi-konsekuensi emosional dan tingkah laku). Konsekuensi-konsekuensi (consequences) dalam Model ABCs dilambangkan dengan "C".

Dengan demikian, adversitas (A) akan menimbulkan konsekuensi (C) sehingga A - C. Jika suatu peristiwa adalah sesuatu yang dianggap baik oleh individu maka akan muncul pengalaman emosi dan tindakan yang positif (bahagia, senang, semangat, dan lain sebagainya). Sebaliknya jika suatu peristiwa adalah sesuatu yang dihayati sebagai hal buruk oleh individu maka akan muncul pengalaman emosi dan tindakan yang negatif (sedih, frustrasi, apatis, dan lain sebagainya). Dalam pola ini tampak bahwa emosi dan tindakan yang muncul sebagai reaksi terhadap suatu peristiwa sangat ditentukan oleh pikiran-pikiran, anggapan (dikenal dengan beliefs - "B") individu terhadap peristiwa tersebut. Oleh sebab itu warna dan derajat " $C$ " sebagai reaksi terhadap adversitas "A" sangat ditentukan oleh beliefs "B" (A-B-C).

\section{HASIL DAN PEMBAHASAN}

Beberapa hasil kajian penelitian menunjukan bahwa, komitmen berwirausaha memiliki pengaruh yang positif dan signifikan terhadap keberlangsungan usaha. Kinerja yang dicapai oleh wirausahawan adalah prestasi atau kinerja yang dihasilkan dalam kurun waktu tertentu yang didasarkan pada ukuran kesuksesan non-finansial dalam menjalankan usahanya. Pendapat tersebut didasarkan pada pandangan bahwa wirausahawan selain sebagai pelaku juga bertindak sebagai pemilik usaha. Komitmen berwirausaha yang ditunjukkan melalui kesediaan seseorang untuk menerima dan memper-tahankan nilai-nilai dan tujuan usaha didasarkan pada niat atau hasrat yang kuat, disiplin yang tinggi, dan keteguhan hati yang mengarahkan perilaku seseorang untuk menghasilkan kinerja atau prestasi yang berorientasi pada pengembangan pasar, jumlah pemesanan, kepuasan kerja, kualitas produk, dan kehidupan layak. Hal tersebut tampak menunjukan bahwa dalam komitmen berwirausaha terdapat aspek psikologis, sehingga pelatihan ini fokus dalam peningkatan modal psikologi positif.

Dalam kehidupan sehari-hari berbagai peristiwa banyak kita alami. Beberapa peristiwa diantaranya dihayati sebagai peristiwa buruk yang tidak menyenangkan dan menekan batin, termasuk dalam kegiatan berwirausaha. Setiap peristiwa buruk (adversity) akan menimbulkan konsekuensikonsekuensi bagi individu yang berupa tingkah laku atau emosi tertentu. Suatu peristiwa yang sama seringkali dihayati secara berbeda-beda oleh dua individu atau lebih. Faktor yang menyebabkan munculnya perbedaan penghayatan tersebut terletak pada keyakinan-keyakinan (belief) individu yang menyertai pemaknaan peristiwa tersebut. Pemaknaan secara positif dan proporsional terhadap suatu peristiwa akan membantu individu lebih mampu bertahan terhadap berbagai peristiwa. Sebaliknya pemaknaan secara negatif dan berlebihan terhadap suatu peristiwa akan menimbulkan perasaan lebih tersiksa.

Terdapat beberapa tahapan yang dilaksanakan dalam pelatihan ini. Setiap peserta harus mempelajari ABC-nya, langkah pertama yang perlu dilakukan adalah mengidentifikasi adversitas yang mengganggu resiliensi. Peristiwa yang dianggap adversif oleh seseorang bisa jadi tidak adversif bagi orang lain bahkan bisa dianggap peristiwa yang positif bagi individu lainnya. Untuk mengidentifikasi adversitas yang sering dialami individu 
dapat digunakan rating scale yang memuat daftar peristiwa yang mungkin dialami individu beserta respon tingkat kesulitan dalam menghadapi peristiwa tersebut.

Langkah kedua, dengarkan dengan tekun aliran pikiran-pikiran yang keluar masuk dalam benak (ticker-tape beliefs), yang kadang-kadang diluar kesadaran. Pikiran-pikiran tersebut menentukan bagaimana individu merasa, dan menentukan apa yang akan dilakukan ditengah-tengah adversitas, tantangan, atau pengalaman baru. Setelah itu, dikembangkan kemampuan mengidentifikasi tingkah laku dan perasaan-perasaan spesifik yang muncul akibat pikiran-pikiran (beliefs) tersebut.

Langkah ketiga, mencermati konsekuensikonsekuensi ("C") yaitu perasaan dan tingkah laku atau tindakan pada saat menghadapi adversitas atau tantangan. Perasaan dan tingkah laku adalah hal yang penting karena orang resilien adalah orang yang mampu mengatur emosi-emosinya, dan mampu mengontrol tindakan-tindakannya sehingga dapat merespon secara tepat berbagai situasi yang dihadapinya). Meskipun demikian tidak berarti orang yang resilien setiap saat berada dalam mood yang baik dan tidak pernah gagal. Konsekuensi ("C") memiliki koneksi dengan pikiran-pikiran (beliefs "B"). Jika individu berfikir bahwa hakhaknya telah dilanggar ("B") maka dia akan marah ("C"). Belief kehilangan sesuatu yang berharga atau penting biasanya akan menimbulkan consequence sedih, depresi. Melanggar hak orang lain akan menimbulkan rasa bersalah, menganggap diri terancam akan muncul rasa cemas atau takut.

Kegiatan pelatihan kewirausahaan tentunya memberikan nilai tambah bagi pedagang pasar lokal. Nilai tambah yang dimaksud adalah pedagang pasar lokal memiliki pengetahuan dan keterampilan yang terkait dengan hal-hal yang diperlukan untuk keberlanjutan usaha. Berdasarkan observasi yang dilakukan terhadap pelaksanaan pelatihan dapat dikemukakan bahwa pelatihan tersebut berjalan dengan lancar sesuai dengan yang diharapkan oleh tim pelaksana. Hal ini dengan antusiasnya peserta pelatihan mengikuti materi serta praktek yang diberikan.
Evaluasi kegiatan pengabdian kepada masyarakat dilakukan setelah diadakan pelatihan $\mathrm{Hal}$ tersebut dilakukan untuk mengetahui dampak pelatihan yang dilakukan terhadap:

1. Manfaat yang dirasakan oleh peserta pelatihan terhadap materi ajar yang diberikan dalam bentuk teoritis maupun secara praktek.

2. Peningkatan pengetahuan / wawasan dan keterampilan dalam hal aspek psikologis pengelolaan usaha.

3. Praktek yang dilakukan oleh masing-masing peserta pelatihan terutama yang menjadikan usaha mereka sebagai pekerjaan utama.

\section{KESIMPULAN}

Kegiatan pengabdian kepada masyarakat yang dilakukan mendapat sambutan dan tanggapan yang positif dari pedangan pasar tradisional. Hal ini terlihat pada kesungguhan dan keseriusan mereka mengikuti materi pelatihan. Pelatihan ini merupakan suatu kegiatan yang sangat membantu pedagang pasar local dalam mengelola keberlanjutan usahanya, khususnya yang terkait dengan aspek psikologis. Peserta yang mengikuti kegiatan ini, 90 persen telah memahami cara mengelola keberlanjutan usaha dengan memanfaatkan aspek psikologis. Dengan demikian, mereka dapat menjalankan suatu usaha dan mengelola usaha tersebut dengan baik dan juga mampu menjawab tantangantantangan dan memanfaatkan peluang-peluang yang ada.

\section{UCAPAN TERIMA KASIH}

Ucapan terima kasih kepada Rektor Universitas Negeri Makassar yang telah memberikan dana PNBP dalam pelaksanaan kegiatan ini. Selanjutnya ucapan terimakasih kepada Ketua Lembaga Pengabdian Pada Masyarakat UNM dan pedagang pasar lokal yang telah memfasilitasi kegiatan.

\section{DAFTAR PUSTAKA}

Bhatt, E, We are poor but so many: the story of self employed women in India, Oxford: Oxford University Press, 2006. 
Bhowmik, S. K, Street vending in urban India: the struggle for recognition. In J. Cross and A. Morales (Eds.), Street entrepreneurs: people, place and politics in local and global perspective (pp. 89-123), 2007.

Hasan, Muhammad, Karakteristik Tenaga Kerja Industri Kecil, Jurnal Ekonomi Pembangunan dan Pertanian, Vol. 2, No. 1, 2013.

Hasan, Muhammad, Produktivitas dan Elastisitas Kesempatan Kerja Sektor Industri, Jurnal Economix Vol. 2, No. 1, 2014.

Hasan, Muhammad, Pengembangan Pola Pendidikan Ekonomi Informal Sebagai Upaya Untuk Pembentukan Perilaku Ekonomi yang Baik. Prosiding Seminar Nasional "Mega Trend Inovasi dan Kreasi Hasil Penelitian dalam menunjang Pembangunan Berkelanjutan" Halaman 82-87, Makassar: Lembaga Penelitian UNM, 2016.
Hasan, Muhammad, Pendidikan Ekonomi Informal dan Literasi Keuangan, Prosiding Seminar Nasional "Membangun Indonesia melalui Hasil Riset" Halaman 677-680, Makassar: Badan Penerbit UNM, 2017.

Hasan, Muhammad, Pembinaan Ekonomi Kreatif dalam Perspektif Pendidikan Ekonomi, Jurnal Ekonomi dan Pendidikan (JEKPEND) Vol. 1, No. 1, 2018.

Hasyim, Hajerah, dan Hasan, Muhammad, Strategi Pemberdayaan dan Keunggulan Bersaing Industri Kecil, Prosiding Seminar Nasional Dies Natalis ke 56 Universitas Negeri Makassar. Makassar: Penerbit UNM, 2017.

Imran Musa, Chalid and Hasan, Muhammad, The influence of social, economic, and demographic characteristic on working hours of micro, small, and medium enterprises (MSMEs) in Makassar City. Journal of Physics: Conf. Series 1028 012181, 2018. 